\title{
Stefania Battistelli
}

University of Urbino Carlo Bo

\section{Piera Campanella}

University of Urbino Carlo Bo

\section{SUBCONTRACTING CHAIN AND WORKING CONDITIONS IN ITALY: EVIDENCE FROM THE FOOD AND MEAT INDUSTRY*}

\begin{abstract}
Outsourcing is a phenomenon that combines business strategies, structural characteristics of companies and working relationships. In Italy outsourcing is widespread, facilitated by a legislation that has removed limits and made the outsourced production and the management of the workforce easier. As a result, employment, working conditions and industrial relations in the value chain have been affected by this phenomenon in terms of high fragmentation and work protection. In this scenario the industries which have been more negatively impacted by the phenomenon are the ones under high pressure from large retailers and the demand for low cost goods, such as the logistics and the meat sector. The article aims at presenting the analysis of outsourcing phenomenon in Italy, by examining its causes, its mechanism and its consequences on workers and their trade unions. In this context, an inadequacy of the present regulatory approaches in addressing the phenomenon of outsourcing has been observed. Its content has been enriched with the analysis of a case study, called "Modena system," which unveils the weaknesses of outsourcing in a specific sector, the meat industry, and the concrete responses taken by the public actors and trade unions to deal with them.

Słowa kluczowe: outsourcing, podwykonawstwo, warunki pracy, pośrednictwo pracy, przemysł spożywczy i mięsny

Keywords: outsourcing, subcontracting, working conditions, labour intermediation, food and meat industry

ASJC: 3308, JEL: K31

* This article has been prepared during the implementation of the project "Fairness, freedom and Industrial Relations across Europe: UP AND DOWN THE MEAT VALUE CHAIN (MEAT.UP.FFIRE)"VP/2017/004/0035. The article was the product of a joint endeavour between the two authors, but the paragraphs can be attributed as follows: $\$ \S 2,3.1$. to Stefania Battistelli and $\$ \$ 1,3.2$. and 4 to Piera Campanella.
\end{abstract}




\section{Contracting, subcontracting, outsourcing: the Italian solution to reducing the cost of labour}

There is a link between business strategies, the structural characteristics of firms, and working relationships. In the last thirty years, companies' choice to focus on core competencies and outsource other activities has made production networks highly fragmented. Outsourcing has created a disintegration of the value chain. It has also led to a redefinition of the boundaries of a company, making them much more fluid. It has been rightly observed that "any change in company boundaries is likely to impact employment, working conditions and industrial relations in the value chain" (Drahokoupil 2015 , p. 9). Today, as a consequence of company strategies to focus only on a narrower segment of activities, workplaces have changed. Many jobs have shifted away to be performed by separate employers, and now the basic terms of employment are determined by multiple organisations. This is known as "workplace fissure" and it puts great pressure on employment protection. "By shedding direct employment, lead business enterprises select from among multiple providers of those activities and services formerly done inside the organization, thereby substantially reducing costs and dispatching the many responsibilities connected to being the employer of record" (Weil 2017, p. 4). The current workplace statutes have not kept up with this change in employment dynamics, leading to difficulties protecting workers. Consequently, lead companies gain profitability, while workers at lower levels see their working conditions worsen, in terms of wages and other benefits such as healthcare, pensions and job security. Furthermore, this outsourcing of responsibility down the chain towards external, smaller contractors and third parties leads to a lack of accountability, often creating conditions that violate workplace laws.

The impact of outsourcing on employment is certainly visible in the case of offshore outsourcing, when the lead company transfers operations to other countries. Such dynamics create unemployment within the lead company's country, and also form global supply chains that are plagued by problems with the protection of working conditions (Drahokoupil 2015, pp. 10-11), due to the fact that offshoring is in part motivated by cost reduction.

However, this impact is also evident when outsourcing is not linked to offshore strategies, but simply to the transfer of operations to third parties within the same country. In Italy, this practice became widespread in the 1990s, helped by legislation that removed limits and made outsourced production more convenient. Despite the fact that Italy has seen less development of outsourcing than many other European countries (ISFOL 2011, pp. 14-15), and the challenges posed to this strategy by the digital revolution, ${ }^{1}$ outsourcing remains an attractive option for Italian companies. A second wave of out-

1 There is debate on the future of outsourcing in the age of digitalisation, which could threaten the success of this form of production. However, it seems that new technologies, rather than eliminating outsourcing, are transforming it (Deloitte 2018). 
sourcing appeared after the 2008 financial crisis as a solution to economic problems faced by both the public and private sectors. In the former, outsourcing has often been used to bypass the ban on hiring new public employees imposed by European austerity policies (Dorigatti, Mori 2016, p. 194). In the latter, instead, outsourcing has been practised for survival, enabling smaller companies to cope with the effects of the recession. Still today, outsourcing remains a fundamental tool for the restructuring of entire sectors, such as banking, which have been severely hit by technological development. ${ }^{2}$

Much of the growth of outsourcing is due to the increasing importance of logistics (Bologna, Curi 2016, pp. 126-133; Grappi 2016). This is an area of the Italian labour market strongly affected by the phenomenon of the "working poor," due to the growth of not only precarious work, but also indirect work (a more general analysis of the phenomenon of precarious work in Europe: Kenner, Florczak, Otto 2019; regarding the phenomenon of the working poor in Italy and its connection to logistics: CNEL 2014). Logistics services are frequently outsourced, provided by smaller companies, often in the form of cooperatives. Furthermore, logistics is a labour-intensive sector with many migrant workers occupied in low-skilled jobs. It spans all sectors, including those in which Italy is a world leader, such as food production.

In recent years this industry has been under a lot of pressure from large retailers and their demand for low-cost goods. This is particularly true for the meat industry, which is the biggest area of production in the European agro industrial sector. Italy is one of the most competitive producers in this market, particularly in the production of cured meats, which is confirmed by the growth in its workforce, of which $29 \%$ are foreign workers (Battistelli 2019, p. 3).

The need to reduce costs and increase flexibility, in order to meet the demands of large retailers, is easier to resolve in the poultry sector. Here, the high level of integration in the production chain, made possible by the soccida system, ${ }^{3}$ allows large poultry companies to have control over the higher parts of the chain, as far as breeding, and therefore make use of agricultural unemployment benefits that favour more flexible management of the workforce. Furthermore, these benefits are often combined with the use of agricultural collective agreements, which permit lower wages than the collective agreements for the food industry. ${ }^{4}$

${ }^{2}$ In a general context of downsizing in the banking sector, hit first by the financial crisis, and then by technological progress, see the cases of Deutsche Bank or Unicredit, both of which involved largescale dismissal of employees outsourcing can be a useful tool in order to avoid immediate redundancy of workers (Agazzi 2019).

${ }^{3}$ Similar to the term "agistment" in English. This is an agricultural contract in which a large producer assigns an operation to a third party, but retains complete control over it, as if it were still an internal operation. This provides producers with a high level of power over the initial farming process, even if they, in turn, are under pressure from the large retailers.

${ }^{4}$ Collective bargaining in Italy is built on two hierarchical levels: the industry-wide collective agreements struck at the national level by the sectoral federations of social partners, and the company level agreement, or, more rarely, territorial agreements. In recent years, despite the fact that the company 
To the contrary, in the pork sector, where the value chain is very fragmented (Barberis et al. 2019), it is more difficult to manage the pressure from large retailers, which has recently further increased due to African swine fever. This is particularly true for slaughtering and butchery, which is characterised by small-scale companies that are dominated by a few large cured meat producers and forced to adhere to a "just in time" production policy. This places the slaughtering and butchery companies in a position where they have to greatly reduce their costs in order to stand a chance against the competition. They therefore resort to sub-contracting parts of the process-very close to core business-to logistics companies, allowing them to apply logistics collective agreements as an alternative way to circumvent the higher wage requirements of the food industry agreements (contractual dumping). In many cases, these methods approach the limits of legality, or are completely illegal, due to the fact that the subcontracting of services to logistics companies (often sham companies) frequently involves vulnerable migrant workers in illegal labour intermediation practices and violation of general labour laws.

\section{Labour as a service: The legal advantages of indirect employment}

In Italy, several measures have been adopted over the years aimed at outsourcing production processes. The result is a legal framework that not only encourages the use of such operations, but also fosters more flexibility in employment relations.

In 2003, the law introduced a new, broader concept of the transfer of part of an operation (Art. $2112 \$ 5$ of the Civil Code, as modified by Art. 32 of Legislative Decree no. 276/2003, the so-called Biagi Law). The law establishes that the same rules applying to the transfer of an operation may be applied to any part of it identified as a "functionally independent division of an organized economic activity" by the transferor and the transferee at the moment of the transfer. Consequently, the contractual parties are now entitled to identify the part to be transferred at any time, with complete freedom of action, by outsourcing not only parts of the production process, but also existing employment relations. However, the possibility of transferring parts of the production process, as well as the employment relationships involved, might represent a way to hide a reduction in labour force or jeopardize employment or professional prospects.

There are similar concerns with another provision introduced by the same controversial law. With the aim of increasing the scope of lawful service contracts, the abovementioned law provides a broad legal notion of these contracts (Art. $29 \$ 1$ ). According to the new regulation, the contractor must (a) organize the necessary resources or have organizational and managerial power over the contract workers, and (b) assume

level bargaining has been playing a growing role, the core of the system is still to be found in national, sectoral bargaining. 
the contractual risks. Hence, even labour-intensive contracts, with a small proportion of equipment and capital compared to labour, are included within the scope of the discipline under examination. In this regard, it has been observed how difficult it has become to recognise the lawfulness of such operations, which may conceal illegal interpositions in labour where the contribution of these operations consists mainly (or exclusively) in workforce management. ${ }^{5}$

Consistent with the regulatory measures described above, and aimed at making outsourcing processes more convenient, the law repealed the equal treatment principle set out in Art. 3 of Law no. 1369/60 for both contracting-out company's workers and contractors, and any subcontractors' workers within the worksites of the lead company (Art. 85 of Legislative Decree no. 276/2003). The repeal of this principle allows the contractor to apply any collective agreement without being bound to use the same collective bargaining as the contracting-out company. A similar situation is found in the case of service contract changes. According to this provision, also contained in the Biagi Law, when outsourced contracts are replaced by new contracts, workers can no longer enjoy the rights matured in the previous contract (such as the employment relations and the collective agreement applied before) ${ }^{6}$ These contract changes are widely used in labour-intensive sectors in order to maintain flexibility.

However, the repeal of the equal treatment rule has also been "balanced out" by the same law, strengthening the joint liability scheme between the client company, the contractors and any subcontractors with regard to salaries, social security payments, and insurance premiums payable in favour of the contractors' or subcontractors' employees for the period in which the contract was in force. Nevertheless, this provision was amended many times over the years with the aim of weakening the scheme. As a result, today it can also be partially derogated in peius, according to Art. 8 of Legislative Decree no. 138 of 2011, by collective agreements at local and company level. Despite this, the joint liability scheme represents at present the only legislative measure available for assessing the reliability of contractor companies and their financial solvency.

${ }^{5}$ It is worth noting that the jurisprudence has clamped down on the (dangerous) broad definition of the lawful service contracts, by expressing for labour-intensive contracts the concept of autonomy of the productive result of the contractor, as an index to exclude that the tasks outsourced are related to the activity of the contracting out company (judgment of Court of Cassation of 23 January 2013, No. 1630; judgment of Court of Cassation of 7 February 2017, No. 3178; judgment of Tribunal of Reggio Emilia of 13 February 2018, No. 41; judgment of Tribunal of Roma of 19 February 2019, No. 1614).

${ }^{6}$ According to Art. $29 \$ 3$ of Legislative Decree no. 276/2003, when outsourced contracts are replaced by new contracts, the following criteria must be met: a) the new contractor must have a proper economic organization and $b$ ) the service performed for the new contractor must include some aspects that determine a specific business identity different from the original contractor, so the workers cannot longer enjoy the rights matured in the previous contract. If the above-mentioned criteria are met, the result is that, at individual and collective level, the guarantees provided for the transfer of a part of an undertaking will not be applied. 


\section{Illegal practices of indirect employment: a way to circumvent labour laws, social insurance and tax}

\subsection{Labour intermediation, informal work and exploitation of workers}

As a result of legislators' inclination to boost the use of outsourcing practices and fragment work organisation, a growth in contracting-out practices has been observed over the years in Italy. Nonetheless, prioritising the reduction of labour costs over responding to organisational and production demands has caused the adoption of practices at the limits of legality, if not beyond the limits of the law.

To understand the illegal practices underlying outsourcing, it is necessary to reflect first of all on the subcontracting agreement and its object.

Indeed, hidden in a service contract, it is not uncommon to find outright labour intermediation, which is illegal when certain conditions are not present, such as the involvement of an employment agency specifically authorized in labour outsourcing (Art. 20-30 of Legislative Decree no. 276/2003). In these cases, the labour intermediation is punishable, although the most recent legislative interventions have weakened the penal sanctioning regime, making it more difficult to counter the practices of illegal labour intermediation. ${ }^{7}$

In this context, workers are formally employees of the contractor but, in reality, they comply with the directives of the lead company, which organises and controls them as if they were its own workers. The fact that the contracting-out company significantly interferes with the management of the contracted workers reveals that the case could involve illegal intermediation rather than a service contract. If this is proven in court, the law not only punishes both the lead company and the contractor, but also provides workers with employee status at the lead company. In this regard, the jurisprudence has developed criteria for revealing the unlawfulness of the contract. According to these criteria, if the subcontractor provides the client company with a service closely connected to its production cycle, maintaining only the administrative management of the workforce without real organization of the service itself, this is considered an illegal contract (judgment of Court of Cassation of 7 February 2017, No. 3178; judgment of Court of Cassation of 26 October 2018, No. 27213). These situations, involving foreign workers,

${ }^{7}$ In Italy, the only way to carry out legal labour intermediation is through authorised Agencies. If the temporary work is performed by an unauthorised Agency, the Art. $18 \$ \$ 1,2$ of Legislative Decree no. 276/2003 applies an administrative sanction-from a minimum of euros 5,000 to a maximum of euros 50,000 (as modified by Legislative Decree no. 8/2016) - to both the contracting out company and the contracted company (while before a penal sanction was levied). In addition, in case the temporary work is performed with the specific purpose of getting around the compulsory law or collective agreement (so-called "fraudulent labour intermediation"), the Art. 38-bis of Legislative Decree no. 81/2015, as introduced by the Legislative Decree no. $87 / 2018$, provides a penal sanction based on a fine ranging from 20 euro for each irregular worker and day. 
often result in labour exploitation and illegal intermediation, punishable as a crime by Art. 603 bis of the Criminal Code.

To protect against labour exploitation and illegal intermediation, Art. 603 bis of the Criminal Code, as modified by Law no. 199/2016, can punish both the so-called "caporale" gangmaster (who recruits workers for employers through illegal intermediation activities) and the employer (who uses, hires or employs these workers). Based on symptomatic indicators of labour exploitation, ${ }^{8}$ this law could play a crucial role in combating this phenomenon but, despite its aim, the law has certain weaknesses because its application is subject to the presence of two elements with vague definitions: the exploitation of labour (despite the inclusion of symptomatic indicators in this regard) and the use of workers' needs. As a consequence, apart from the most extreme situations of exploitation and intimidation at work, there is a "grey area" which is not addressed by the criminal sanction.

\subsection{Bogus cooperatives, consortia and simplified LTD companies: Contracting out to sham enterprises}

The second important element for the understanding of illegal practices underlying outsourcing is to consider the characteristics of the contracted company, as well as the subcontracting mechanism.

Regarding these characteristics, firstly, the contracted companies in these cases are often in the logistics sector, which is particularly affected by illegal labour intermediation and exploitation of workers (INL 2018, p. 23). This is demonstrated by various agreements aiming to prevent such practices, among which is the recent pact between regional institutions, state inspection agencies and employers' associations in the Lombardy region, against false subcontracting and organised crime in logistics (Chiale 2019).

Secondly, contractors are predominantly set up as small or micro workers' cooperatives. Indeed, being set up as a cooperative has two advantages: fiscally, cooperatives benefit from certain favourable tax regulations, while in terms of labour, they can hire people as shareholders, removing the requirement to provide them with the legal protections given to employees (see Law no. 142/2001).

Thirdly, there is an evident fraudulent nature to the cooperatives involved in such contracts, often revealed to be sham companies (Eurofound 2017). In some cases, these cooperatives already exist, but in others, they are created ad hoc by the lead company, and in both cases, they are not affiliated with any cooperative associations. Furthermore, they use "pirate contracts," signed by small, unknown, or even "fake" unions created

8 The symptomatic indicators of labour exploitation provided by the law consist of: (a) setting wages below the level fixed by national collective agreements or in any way disproportionate to the quantity and quality of performed work; (b) repeating violation of regulations concerning work-hours, compulsory leave and holidays; (c) violating health and safety regulations in the workplace; (d) degrading working conditions, using methods of surveillance or promoting unacceptable housing conditions. 
specifically for the purpose of signing a collective agreement containing fewer rights and protections. Upon closer examination of these contracting companies, we can establish either that they are not really cooperatives, as they lack the mutual purpose required by law, or even that they are not real enterprises, because they do not have physical headquarters, or the necessary means to form a company, such as capital and equipment (Commissione... 2019, pp. 29-52).

After many scandals involving these contracting companies, and various legislative interventions with the aim of stopping the practice of bogus cooperatives, ${ }^{9}$ the companies have started to abandon this form in favour of becoming simplified limited liability companies.

Regarding the mechanisms involved in subcontracting, a new model has emerged over the years, based on the intermediary role of a consortium, used to create distance between the lead company and the subcontractors. In this context, a mechanism of tax evasion has been observed, in which tax obligations are passed down the subcontracting chain until they fall on the bogus companies, which go bankrupt before the state ever receives the payments. Beyond such tax evasion, these situations are also accompanied by the denial of many workers' rights (social security contributions, health and safety, regular payment, non-discriminatory wages, etc.), as well as the creation of fraudulent payslips in which wages are not completely and/or correctly declared.

\section{Evidence from the meat industry: Trade unions, enterprises, and public institutions after the exposure of the "Modena case"}

There is much evidence of such phenomena in the meat industry. The reason why companies contract out many activities-including core operations-to logistics cooperatives, is connected to the fact that they are included in the regulation creating a favourable system of social security contributions, and defined as carrying out "comprehensive (pure) activities that are preliminary and complementary to the movement of goods and products," including "matting, skinning, grooming and slaughtering" (Ministerial Decree of December 3, 1999, referring to Presidential Decree no. 602/1970). This seems to legitimise the extension of logistics services to slaughtering activities. Furthermore, it has made the legal form of the cooperative very convenient for social security contributions.

The existence of these mechanisms has weakened the position of the union confederations and their ability to fight the subcontracting system. These unions have mostly continued to represent direct employees-a minority group of mainly older,

9 See the Financial Law for the year 2018, which contained a series of provisions with the purpose of fighting against bogus cooperatives, as well as Emilia-Romagna Law no. 18 of 28 October 2016, regarding the promotion of legality, and the special regional Research and Study Commission about bogus cooperatives. 
Italian workers-who are often supportive of subcontracting the most strenuous, low-skilled tasks.

However, over time, the increase in exploitation linked to this low cost model of employment has led indirect workers-mainly younger, vulnerable migrants-to take action. In the province of Modena (Emilia-Romagna Region), an area with a high concentration of meat production, where subcontracting to fake cooperatives is widespread (Battistelli et al. 2019) the lack of representation for these workers has left room for new autonomous trade unions, such as SI Cobas. Due to its intersectoral nature, this union has penetrated the logistics sector in the northern part of Italy, and has become the "migrants' union" par excellence, carrying out conflictual action inspired by class solidarity.

In some cases, CGIL, one of the three union confederations, has also been involved in industrial action for indirect and migrant workers, becoming a main actor in radical protests and strikes. These actions have impacted union strategies, such as new forms of union representation, internal union organisation, and cooperation among union federations, allowing them to become more inclusive of indirect workers (see Progetto Carni, Meat Project, of FLAI-CGIL and CGIL E.R., whose main objective is to provide a single workplace union structure for direct and indirect employees on the same site or in the same area). More generally, this kind of industrial conflict has revealed a system of exploitation of workers, and tax evasion, based on illegal subcontracting. This has pushed regional and national institutions to intervene in the situation, albeit without particularly effective solutions.

The most extreme cases of labour intermediation and exploitation are now declining in the Modena area, but the general problem of the subcontracting system and subsequent fragmentation of the workforce and the production chain remains. The fight to expose such exploitation has also cost the unions greatly, especially in the case of CGIL, which has lost the membership of direct workers in some cases, found itself in conflict with one of the other three union confederations at a local level, and been blamed for the failure of one of the companies involved in such illegal practices (see the case of Castelfrigo, a pork company that, after a bitter industrial conflict led by FLAI-CGIL Emilia-Romagna, went bankrupt). Unfortunately, the rights won in the process have not been proportional to the losses sustained, as adequate protection for indirect workers is still not ensured.

Considering the situation, it may be necessary to change gear. This process must start from having the courage to admit that some sectors, such as the pork business, deal with global competition by using models that are at the limits of legality, if not completely illegal. Only after such an admission can possible solutions be found, with the full involvement of public institutions, as well as trade unions, enterprises and employers' associations. The public institutions must also have the courage to implement reforms in order to confront violations of fiscal, social and labour laws. For example, legislation is needed to strengthen the rights of shareholders of cooperatives, to re-establish equal treatment of direct and indirect workers, particularly when they are involved in 
the same production cycle, as well as to introduce fiscal mechanisms in order to prevent tax evasion in the supply chain ${ }^{10}$. At the same time, it would be useful to bring industrial policies to the table that would requalify the systems of production on a local level, ensuring a higher quality of products, labour , and environmental sustainability. These policies should be supported by more awareness on the part of companies of the need for unity and integration between different levels of the supply chain (breeding, slaughtering and butchery, processing), as well as between different companies within each level (primarily slaughtering and butchery) in order to reinforce their position in the market and better face the pressure from large retailers, one of the biggest problems in the meat value chain.

\section{References}

Agazzi D. (2019) Esternalizzazioni Ubi, Salvoldi (Cisl): "Soddisfaatti per laccordo raggiunto", https://www.bergamonews.it/2019/12/04/esternalizzazioni-ubi-salvoldi-cisl-soddisfattiper-laccordo-raggiunto/340826/ (access: 20 January 2020).

Barberis E., Centamore G., Freddi D., Giammetti R., Polidori P., Teobaldelli D., Viganò E. (2019) WP2: Structural Characteristics of the European Pork Meat Value Chain: A Quantitative Analysis, https://drive.google.com/file/d/1eKLyXFG1gZFqgwpP3iVhk0stTWy3eoLO/view (access: 20 January 2020).

Battistelli S. (2019) Tecniche regolative della sicurezza sul lavoro negli appalti e nelle esternalizzazioni. Il caso delle carni, $\mathrm{PhD}$ thesis, Urbino.

Battistelli S., Campanella P., Centamore G., Dazzi D., Freddi D. (2019) WP3: National Report, Italy. Industrial Relations in the Pork Value Chain, https://drive.google.com/file/d/1JagPv1 jOO7f7iNU5Mgu6BiaMFOTQsK_v/view (access: 20 January 2020).

Bologna S., Curi S. (2016) Relazioni industriali e servizi di logistica: uno studio preliminare, "Giornale di diritto del lavoro e di relazioni industriali," Vol. 161.

Chiale S. (2019) Stop caporalato e appalti truffa. Patto-legalità tra le cooperative. Accordo su logistica e ispezioni, "Corriere della Sera Milano," 15 October.

CNEL (2014) Working poor: unanalisi sui lavoratori a bassa remunerazione dopo la crisi, Roma. Commissione speciale di ricerca e di studio sulle cooperative cosiddette spurie o fittizie (2019) Relazione conclusiva, https://www.assemblea.emr.it/ (access: 20 January 2020).

Deloitte (2018) Traditional Outsourcing is Dead. Long Live Disruptive Outsourcing. Global Outsourcing Survey.

Dorigatti L., Mori A. (2016) L'impatto delle scelte datoriali sulle condizioni di lavoro e sulle diseguaglianze: disintegrazione verticale, esternalizzazioni e appalti, "Sociologia del lavoro," Vol. 144.

${ }_{10}$ An example is the so-called "reverse charge," a mechanism that imposes an advance payment of taxes on the lead company in order to prevent tax evasion on the part of subcontractors. There have been attempts to introduce this mechanism from 2019 onwards, but they have only been partially successful. 
Drahokoupil J. (2015) Introduction [in:] J. Drahokoupil (ed.), The Outsourcing Challenge. Organizing Workers across Fragmented Production Networks, Brussels.

Eurofound (2017) Fraudulent Contracting of Work: Sham Companies (Austria, Estonia and Italy), Dublin.

Grappi G. (2016) Logistica, Roma.

INL (2018) Rapporto annuale sull'attività di vigilanza in materia di lavoro e legislazione sociale, https://www.ispettorato.gov.it/ (access: 20 January 2020).

ISFOL (2011) Il fenomeno delle esternalizzazioni in Italia. Indagine sull'impatto dell'outsourcing sullorganizzazione aziendale, sulle relazioni industriali e sulle condizioni di tutela dei lavoratori, Roma.

Kenner J., Florczak I., Otto M. (2019) (eds.) Precarious Work. The Challenge for Labour Law in Europe, Cheltenham-Northampton.

Weil D. (2017) The Fissured Workplace. Why Work Became so Bad for so Many and What Can Be Done to Improve It, Cambridge (Mass.).

\section{Court sentences}

Judgment of Court of Cassation of 23 January 2013, No. 1630, https://sentenze.laleggepertutti.it (access: 14 January 2020).

Judgment of Court of Cassation of 7 February 2017, No. 3178, https://sentenze.laleggepertutti.it (access: 14 January 2020).

Judgment of Tribunal of Reggio Emilia of 13 February 2018, No. 41, https://sentenze.laleggepertutti.it (access: 14 January 2020).

Judgment of Court of Cassation of 26 October 2018, No. 27213, https://sentenze.laleggepertutti.it (access: 14 January 2020).

Judgment of Tribunal of Roma of 19 February 2019, No. 1614, https://sentenze.laleggepertutti.it (access: 14 January 2020). 